\title{
P361: Biomedical waste management in hospitals: the case of large burned: the burn centre center of Abidjan
}

\author{
R Oyourou*, J Sissoko \\ From 2nd International Conference on Prevention and Infection Control (ICPIC 2013) \\ Geneva, Switzerland. 25-28 June 2013
}

\section{Introduction}

Biomedical waste presents potential hazards for people who generate it in healthcare settings or individuals who handle or are exposed to it after its mismanagement.

\section{Objectives}

To investigate the knowledge, attitudes and practices of medical waste management in Abidjan's Burn Center.

\section{Methods}

Prospective preliminary study type cross-sectional, made over a period of two weeks on the types of medical waste and the analysis of knowledge and practices of personnel. The study involved 13 nurses, 05 doctors 10 aides, and 2 maintenance agents.

\section{Results}

The majority of the waste is needles and syringes, gauze, gloves, pouches blood, infusion sets, urine bags, tubes, vials of injectable ampoules cotton and pharmaceutical waste.

Regarding knowledge of risk medical waste: $96 \%$ know the risks of mismanagement of medical waste; there is no waste sorting prior to garbage collection. After dressing, the waste shall revert to the central waste bin are all set in the same trash bag and dumped without every day in the central bin. The needles are pre-stored in bottles. Proper equipment for better waste management is inadequate as $96 \%$ of respondents. Medical waste is collected, does not undergo any treatment and is transported to the landfill Akouedo a service provider. In addition, no health staff received training on the management of biomedical waste and no campaign has been carried out in the center.

\section{Conclusion}

This study shows the need to strengthen the process of medical waste management in a burn center through education, training and the provision of adequate equipment.

\section{Disclosure of interest \\ None declared.}

Published: 20 June 2013

\section{doi:10.1186/2047-2994-2-S1-P361}

Cite this article as: Oyourou and Sissoko: P361: Biomedical waste management in hospitals: the case of large burned: the burn centre center of Abidjan. Antimicrobial Resistance and Infection Control 2013 2(Suppl 1):P361.

SAMU-Cl, Great Burn Center, Abidjan, Côte d'Ivoire

Submit your next manuscript to BioMed Central and take full advantage of:

- Convenient online submission

- Thorough peer review

- No space constraints or color figure charges

- Immediate publication on acceptance

- Inclusion in PubMed, CAS, Scopus and Google Scholar

- Research which is freely available for redistribution

Submit your manuscript at www.biomedcentral.com/submit
() Biomed Central

\section{Biomed Central}

